\title{
First results from radar profiles collected along the US-ITASE traverse from Taylor Dome to South Pole (2006-2008)
}

\author{
Brian C. WELCH, ${ }^{1}$ Robert W. JACOBEL, ${ }^{1}$ Steven A. ARCONE ${ }^{2}$ \\ ${ }^{1}$ Department of Physics, St Olaf College, 1500 St Olaf Avenue, Northfield, MN 55057, USA \\ E-mail: jacobel@stolaf.edu \\ ${ }^{2}$ US Army Cold Regions Research and Engineering Laboratory, 72 Lyme Road, Hanover, NH 03755-1290, USA
}

\begin{abstract}
The 2006/07 and 2007/08 US-ITASE traverses from Taylor Dome to South Pole in East Antarctica provided opportunities to survey the subglacial and englacial environments using $3 \mathrm{MHz}$ and $200 \mathrm{MHz}$ radar. We present first results of these new ground-based radar data. A prominent basal deformation layer indicates different ice-flow regimes for the northern and southern halves of the Byrd Glacier drainage. Buried dune stratigraphy that appears to be related to the megadunes towards the west occurs at depths of up to $1500 \mathrm{~m}$. At least two new water-filled subglacial lakes were discovered, while two recently drained lakes identified from repeat ICESat surface elevation surveys appear to be devoid of water.
\end{abstract}

\section{INTRODUCTION}

The International Trans-Antarctic Scientific Expedition (ITASE) is a multidisciplinary research program whose goal is to reconstruct the recent climate history of Antarctica through ice coring and related geophysical, glaciological and paleoclimate observations along traverses throughout the continent. The US component of ITASE (US-ITASE) operates numerous scientific projects from a heavy traverse platform consisting of two tractor trains. The US-ITASE traverses provided an opportunity to collect ground-based radar data over long distances, covering a wide range of glaciological and geological environments (Fig. 1). A third vehicle, a Pisten Bully used to scout for crevasses ahead of the heavy trains, was available for local radar profiles near the ice-core sites. The size of the traverse trains makes it possible to collect shallow $(200 \mathrm{MHz})$ and deep $(3 \mathrm{MHz})$ radar simultaneously.

The first phase of US-ITASE collected $>3000 \mathrm{~km}$ of deeppenetrating radar data along a series of traverses centered at Byrd Station $\left(80^{\circ} \mathrm{S}, 120^{\circ} \mathrm{W}\right)$ and ending in January 2003 at South Pole. During the second traverse, vehicles drove from Taylor Dome to Byrd Glacier (2006/07 field season) in East Antarctica and then to South Pole via Titan Dome (2007/08 field season). Shallow $(\sim 100 \mathrm{~m}) 200 \mathrm{MHz}$ profiles were recorded simultaneously with deep radar at $3 \mathrm{MHz}$, and both were used in the field to determine the suitability of ice-core sites.

The purpose of this paper is to show first results from both radar systems focusing on features of current glaciological interest: the megadunes area, basal ice-flow regimes and subglacial lakes.

\section{RADAR SYSTEMS}

Altogether we acquired $>2100 \mathrm{~km}$ of deep radar profiles using an impulse system with a center frequency of $3 \mathrm{MHz}$ (Welch and Jacobel, 2003). Recent improvements to the system for this project included a dual-channel digitizing board to record low- and high-gain signals simultaneously, an increase in sampling frequency to $200 \mathrm{MHz}$, and a faster trigger acquisition speed (up to $1.5 \mathrm{kHz}$ ). The transmitter was upgraded to a Kentech pulser with higher amplitude $(4 \mathrm{kV})$ and a pulse repetition frequency of $1 \mathrm{kHz}$. Individual stacked traces (1000 triggers per stacked trace) were recorded at an average spacing of $3.5 \mathrm{~m}$, with trace locations and surface elevations determined by continuously recorded high-precision global positioning system (GPS) measurements. Profiling speeds were as high as $14 \mathrm{~km} \mathrm{~h}^{-1}$ during the traverse.

While stacking traces in the field eliminates much of the environmental noise, some is inevitably present. The impact on data quality is noticeable only in regions of high signal attenuation and ice thickness greater than $3 \mathrm{~km}$ (e.g. deepest segments of Byrd Glacier); however, internal stratigraphy was detected to depths of $>2.7 \mathrm{~km}$.

All $3 \mathrm{MHz}$ data were recorded with the same dualchannel radar system configuration, except that the transmitter-receiver offset in 2006/07 was $207 \mathrm{~m}$ while it was shortened to $125 \mathrm{~m}$ in 2007/08. The shorter offset causes the direct wave to saturate the receiver to nearly $500 \mathrm{~m}$ in the high-gain channel of the 2007/08 data; however, the nearsurface horizons are still recoverable in the low-gain channel.

The shallow radar data were collected with a Geophysical Survey Systems Inc. (GSSI) SIR6 system with a $200 \mathrm{MHz}$ dipole antenna towed in a plastic sled behind one of the traverse trains. Both radars were run on the same sledge train for most of the traverse. Simultaneous GPS observations collected with each radar system allow the datasets to be correlated with accuracy better than $20 \mathrm{~m}$ after consideration of slight differences in travel path due to the long tow ropes of the $3 \mathrm{MHz}$ system.

\section{FINDINGS}

\section{Thick basal ice in upper Byrd Glacier}

Byrd Glacier is one of the major outlets of ice from East Antarctica, and the largest contributor of East Antarctic ice to the Ross Ice Shelf. The deep radar profiles show that the basal ice in the northern half of the Byrd Glacier drainage differs from that found in the southern half. Representative profile sections from these two regimes that we observed continuously for several hundreds of kilometers are shown in Figure 2 and are located on the map (Fig. 3). In particular, 


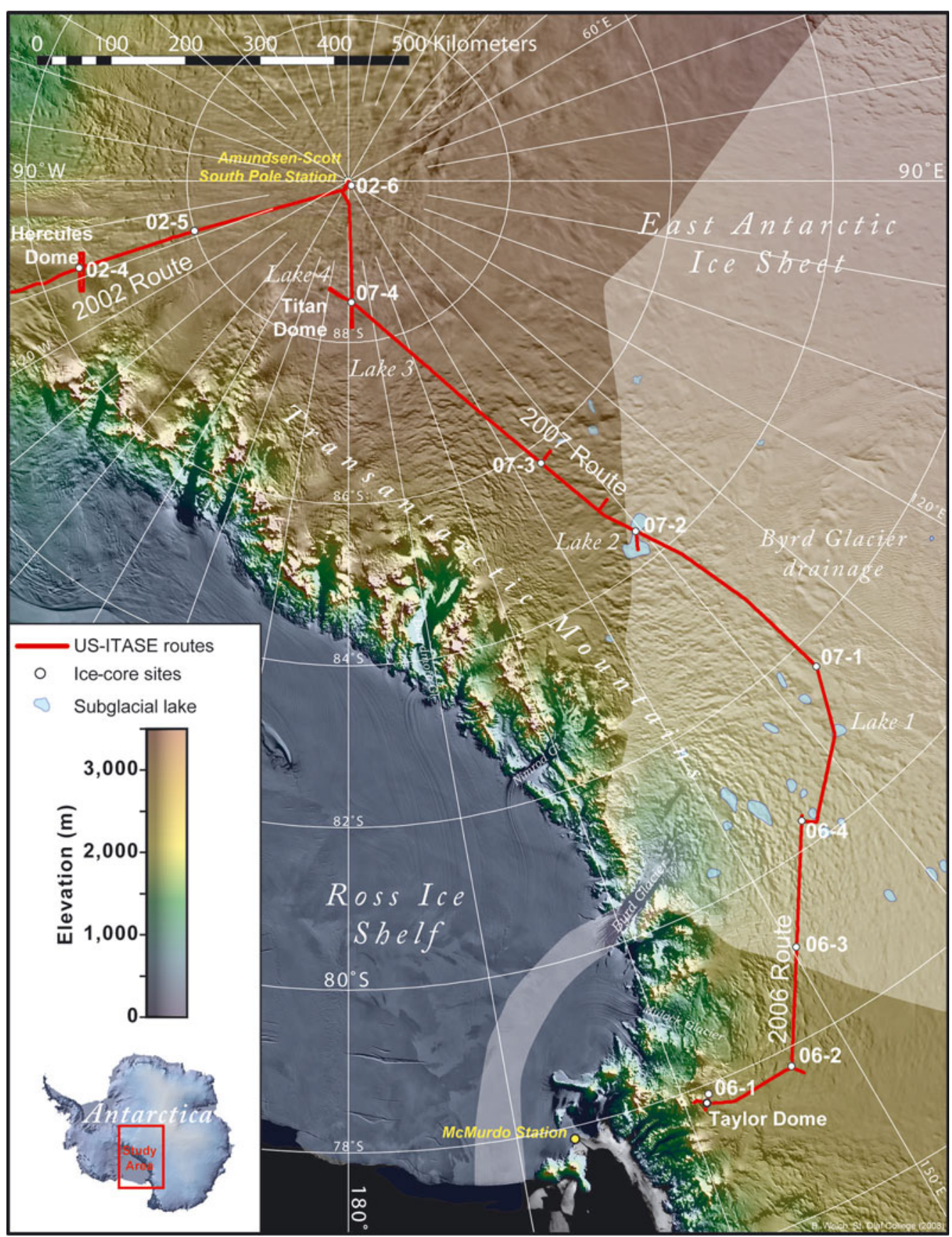

Fig. 1. Shaded relief map showing the US-ITASE routes in East Antarctica (red lines), ice-core sites (white dots) and subglacial lakes from satellite-derived surface elevation changes. Byrd Glacier drainage interpreted from ice surface elevation data. Elevation data from $\mathrm{H}$. Liu and others (http://www.nsidc.org/data/nsidc-0082.html); shading from the MODIS Mosaic of Antarctica (MOA; T. Haran and others, http:// www.nsidc.org /data/nsidc-0280.html).

there is a thick $(>500 \mathrm{~m})$ region of basal ice where there are no internal horizons recovered by the $3 \mathrm{MHz}$ radar (Fig. 2b). The upper ice contains laterally continuous layers. The transition between the upper stratigraphy and the basal ice is marked by what appear to be small fragments of horizons in a 100-200 m thick band. In contrast, the northern half of the Byrd Glacier drainage exhibits internal horizons that are continuous nearly to the bed (Fig. 2a).

The thick basal ice lacking coherent reflectors is found between $81^{\circ} \mathrm{S}$ and $83.75^{\circ} \mathrm{S}$, as shown by the blue line in Figure 3. This zone ends about $80 \mathrm{~km}$ north of ice-core site $07-2$, within $100 \mathrm{~km}$ of the southern margin of the Byrd Glacier drainage basin where deep stratigraphy becomes restored.
The traverse crosses the drainage nearly perpendicular to flow, so the change in basal stratigraphy is not likely to be a result of profile orientation relative to ice flow. Possible causes of the lack of horizons in the near-bed radar data include: (1) increased attenuation, perhaps due to warmer basal ice, (2) disruption of the layers due to upstream basal topography, or (3) higher rates of ice flow in the southern half of the drainage basin. We cannot determine the specific cause of the thicker basal ice without further along-flow radar profiles that would provide constraints on ice-flow models. However, the difference between the northern and southern halves of the Byrd Glacier drainage could have implications for historical or modern ice flow. 

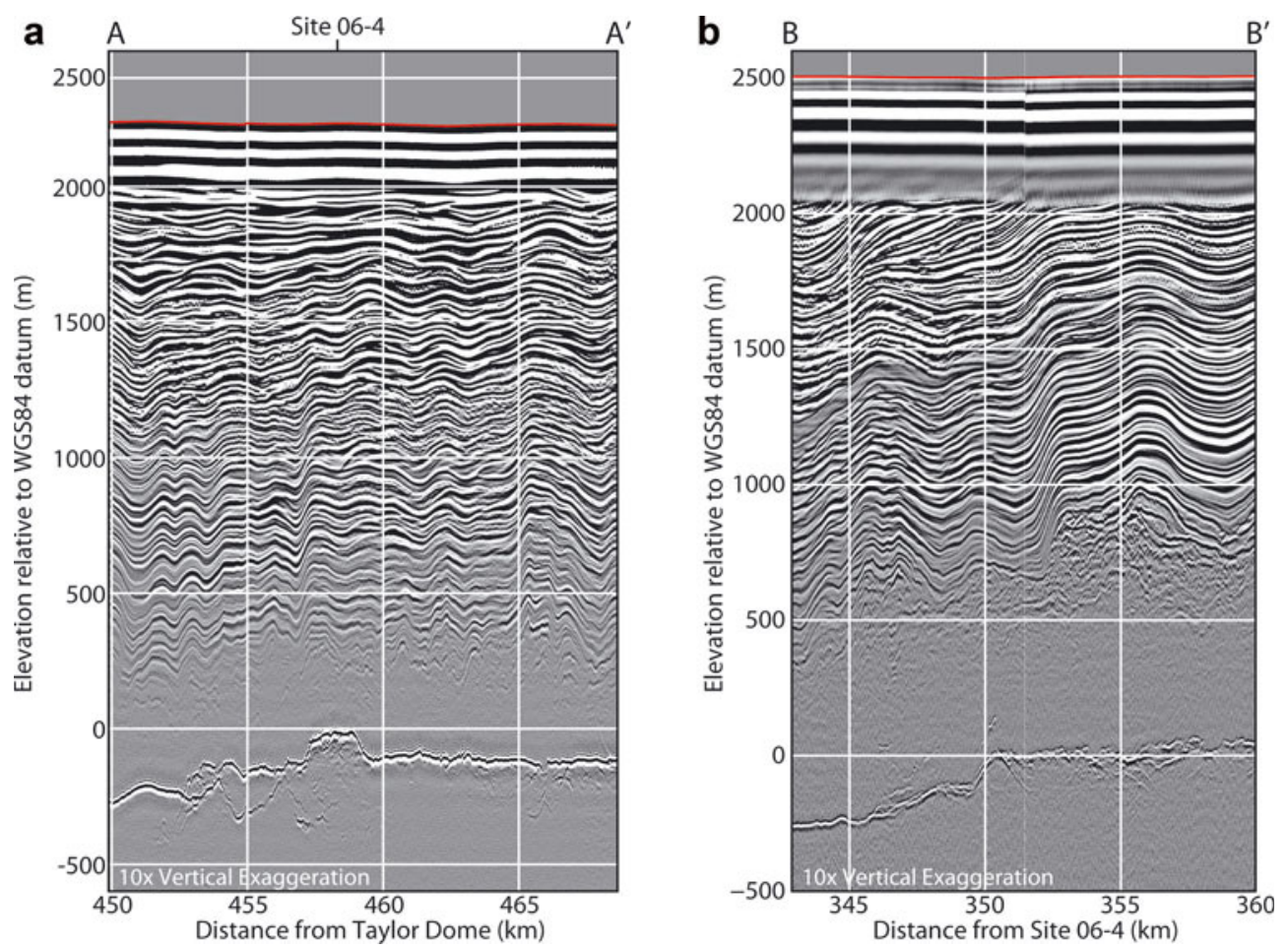

Fig. 2. Representative elevation-corrected profile sections from north and south Byrd Glacier basin. (a) $3 \mathrm{MHz}$ depth-section profile (A-A') from the northern half of the Byrd Glacier drainage. Note that the near-bed reflectors are conformable to one another and are similar in shape to the bed topography. (b) Depth-section profile (B-B') from the 2007 traverse shows that the southern half of the Byrd Glacier drainage is marked by a much thicker basal layer with no stratigraphy and is separated from the upper coherent stratigraphy by a zone of highly disrupted reflectors. The near-surface ringing is greater in $B-B^{\prime}$ due to the shorter transmitter-receiver offset.

\section{Near-surface features}

The addition of a low-gain channel to the radar system allowed the recovery of shallow reflectors that previously had been masked by the power of the airwave arrival. We have correlated the shallow reflectors in our data with data recorded by the $200 \mathrm{MHz}$ radar system to examine several interesting near-surface features found along the traverse route. We find evidence of buried dunes (yellow lines in Fig. 1), aeolian erosion at the surface, and layer deformation due to subglacial topography.

Profile $C-C^{\prime}$ (Fig. 4) shows deep and shallow radar data in a region near the margin of the megadunes (Fig. 3) (Fahnestock and others, 2002; Frezzotti and others, 2002). The $200 \mathrm{MHz}$ radar data show clear evidence of buried dunes in the upper $80 \mathrm{~m}$ of firn. Based on results from the $200 \mathrm{MHz}$ radar, we infer the white bands in the shallow radar profile (e.g. $\mathrm{km} \mathrm{250,} 50 \mathrm{~m}$ depth to $\mathrm{km} 270,5 \mathrm{~m}$ depth) as zones of intense thermal metamorphism (Arcone and others, 2005), which occur throughout $5-15 \mathrm{~km}^{2}$ regions of stratified and buried dunal structures. We interpret the foreset beds in the deep radar profiles directly below these zones to be largescale dunal structures buried up to $1.5 \mathrm{~km}$ within the ice (Albert and others, 2004). This particular location exhibits the greatest stratigraphic disruption due to deep buried dunes seen on the traverse. The magnitude of the disturbed stratigraphy found in this location may result from highly variable accumulation due to changes in airflow around the topographic rise seen upstream in the Mosaic of Antarctica (Fig. 3).

In other areas, the low and even negative accumulation rates in East Antarctica are apparent where the radar stratigraphy intersects the ice surface, usually due to the flow of ice over bedrock topography. These are regions where aeolian transport and erosion exceed local accumulation rates, usually due to surface relief that exposes the surface to higher wind speeds (Welch and Jacobel, 2005). An example is shown in profile D-D' (Fig. 5) between icecore sites 07-3 and 07-4 where the ice flow is within $30^{\circ}$ of the profile direction. Here the ice flows over a subglacial mountain, causing a bulge in the surface. Wind acting on that topographic high increases the aeolian erosion rate to the point where the net mass balance is negative. The intersection of the ice stratigraphy with the surface is seen in both the $3 \mathrm{MHz}$ and $200 \mathrm{MHz}$ radar data. Once dating of the two adjacent ice cores is complete, we may be able to determine the age of the exposed ice at the surface if we can trace stratigraphy back to the erosion site.

These areas where the layers intersect the surface are regions of long-standing and ongoing erosion, generally on the leeward sides of topographic bumps (Arcone and others, 2005; Fig. 5). Such sites were found in many locations between Taylor Dome and Titan Dome and are of great importance for the interpretation of ice-core records, as the aeolian erosion eliminates significant periods of accumulation history and brings older layers near the surface.

\section{Subglacial lakes}

The identification of subglacial lake drainage through timeseries measurements of satellite-derived ice surface topography has emphasized the likely importance of water drainage in controlling local and regional ice flow (Anandakrishnan and Winberry, 2004; Fricker and others, 2007). We utilized maps of subglacial lakes provided by B. Smith (personal communication, 2007) to ensure that the 


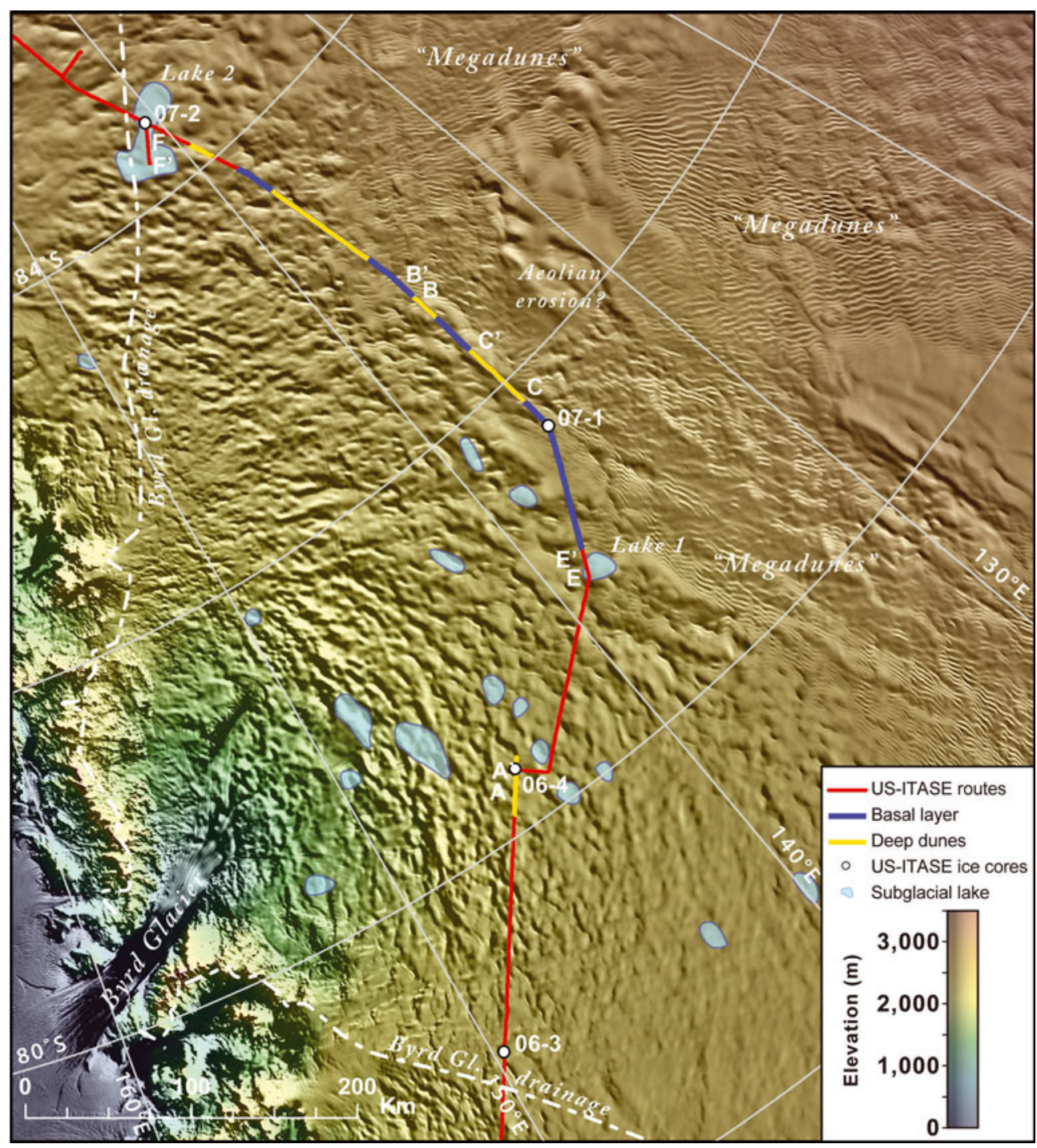

Fig. 3. Locations of thick basal ice zone (blue line) in the southern half of Byrd Glacier. The locations of buried dunes (yellow lines) are superimposed over the thick basal ice and red line of the traverse route.

traverse route crossed a number of these recently drained lakes. In addition, we found at least two other water-filled subglacial lakes that do not appear in the existing lake catalogues.

We crossed the edge of lake 1 (Fig. 3) between ice-core site $06-4$ and site $07-1\left(81^{\circ} \mathrm{S}, 139^{\circ} \mathrm{E}\right)$. The bed is quite rough in the area identified as a subglacial lake (km 140-151), but there is a distinct and abrupt depression in the bed surface (Fig. 6a). There is no indication of higher reflectivity generally associated with subglacial water. Lake 2 is located in the deepest basin crossed during the traverse with ice up to $3.3 \mathrm{~km}$ thick. It is just outside the southern Byrd Glacier zone of thick basal ice, located at or very near the drainage divide between Byrd and Nimrod Glaciers (Fig. 6b).

Lakes 1 and 2 were identified by B. Smith based on rapid deflation of the ice surface elevation, as seen in Ice, Cloud and land Elevation Satellite (ICESat) altimetry measurements (Smith and others, 2007). The cause of the deflation is interpreted to be the drainage of water from subglacial cavities (Fricker and others, 2007). It is important to note that while the basal reflectors are not rough, there are occasional scattering reflectors indicative of bumps or cracks in the ice. These may indicate that the ice lies directly on the bed, which is not as smooth as one might expect for a water-filled lake. The bed at lake 1 is quite rough for a subglacial lake, although there is a deep notch at $\mathrm{km} \mathrm{142-145.} \mathrm{While} \mathrm{the}$ basal reflector at lake 2 is relatively smooth, the low basal reflectivity seen in the $3 \mathrm{MHz}$ radar data leads us to believe that there is currently little or no water present at these sites. This supports the observation of recent drainage and that there has been virtually no subsequent refilling of the basins (Smith and others, 2007). Future work, including modeling of attenuation, is required to develop the quantitative reflectivity of the basal reflectors. However, the apparently low basal reflectivity compared to adjacent regions of rough bedrock at similar depths, leads us to conclude that there is no significant basal water present at these sites at this time (Carter and others, 2007).

Lake 3 is located $40 \mathrm{~km}$ north of Titan Dome (Fig. 1). It is a bright, relatively flat reflector at km 1034-1041 (Fig. 7). The geometry of the local topography would indicate a possible water depth of $10 \mathrm{~m}$ or more. In general, the basal reflectivity in this region is much higher than for lakes 1 and 2 , both of which are within the Byrd Glacier drainage. Englacial stratigraphy is concave upward in this area and visible to within $100 \mathrm{~m}$ of the bed and there is little evidence 


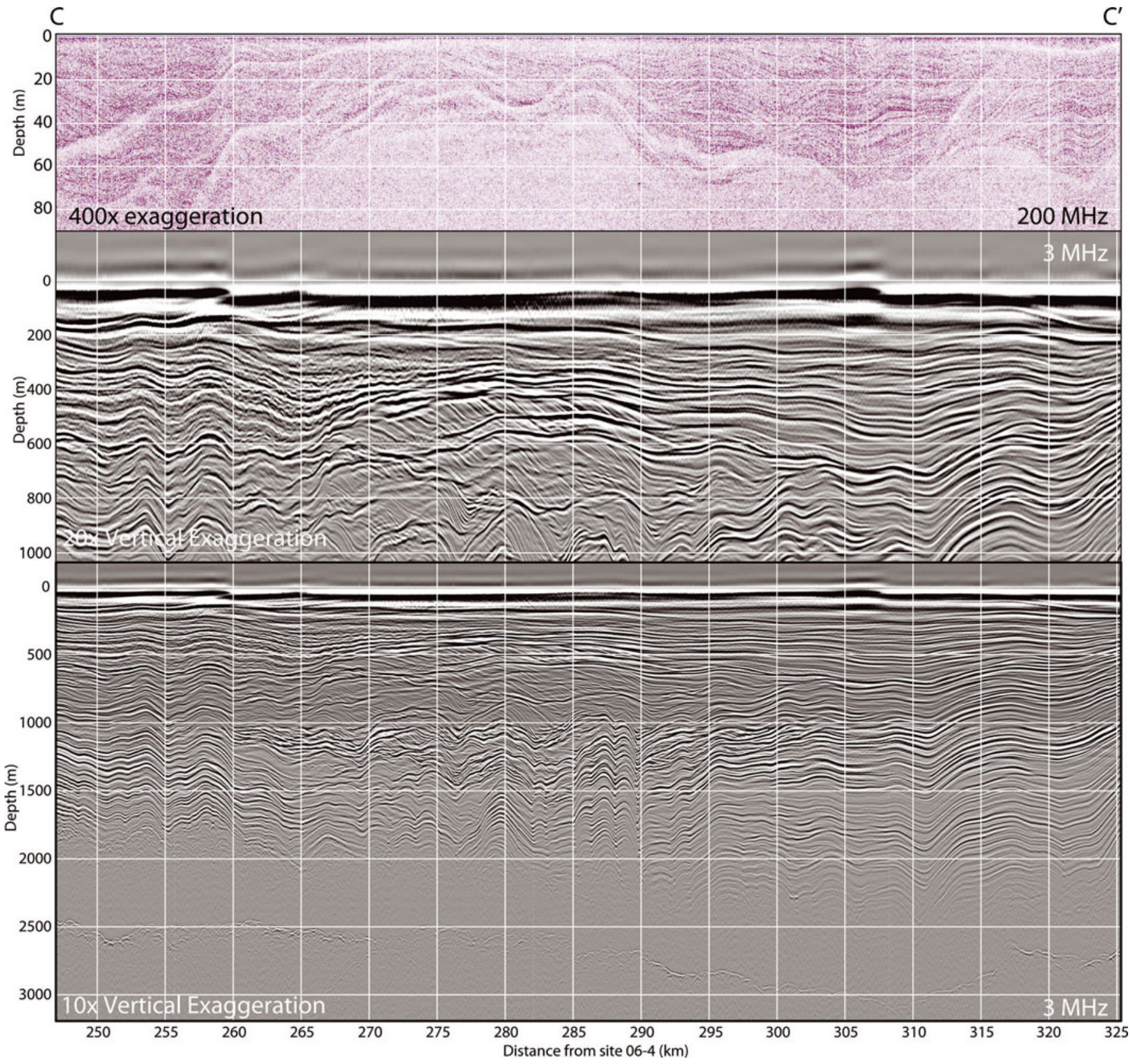

Fig. 4. Profile $C-C^{\prime}$ shows evidence of buried dune structures. (a) $200 \mathrm{MHz}$ data show near-surface dunes. The hazy white bands are interpreted as zones of intense metamorphism. (b) $3 \mathrm{MHz}$ intermediate-depth data from the low-gain channel showing a complex depositional history. (c) Full $3 \mathrm{MHz}$ profile showing relatively simple bed topography.

of a basal ice layer with high attenuation, as was seen in lakes 1 and 2 in the Byrd Glacier drainage.

The relatively high reflectivity and smooth reflector indicates the probable presence of ponded water at km 1034-1041. At km 1046-1055 there is a bright, relatively smooth reflector, at the bed, but it is not horizontal. The diffraction hyperbolas within the basal reflector indicate some basal roughness, but they are mostly masked by the strong smooth reflector. We hypothesize that water in this area is flooding much of the basal roughness, and is perhaps flowing into lake 3.

Lake 4 is a small feature roughly $19 \mathrm{~km}$ southeast of icecore site 07-4 (Fig. 1). The basal reflector is smooth and very intense (Fig. 8). A neighboring reflector $(\mathrm{km} \mathrm{12-15)}$ in an elevated basin is also a very strong reflector, but the roughness implies that the bed topography influences the ice contact.
The presence or absence of subglacial water is an important factor in ice-flow dynamics, and the use of ICESat data to identify the movement of water is a key step in characterizing the extent and activity of sub glacial hydrology. Ice-penetrating radar provides critical information about the extent of water drainage and the morphology of the glacier subsurface that will be needed in order to calculate water flux if any lake empties or starts to refill.

\section{FUTURE WORK}

We are completing the processing of the entire radar dataset, including migration to recover a more accurate geometry of the reflector surfaces, and digitizing reflector horizons for quantitative measurements of total ice thickness and changes within englacial stratigraphy. The digitized layers 


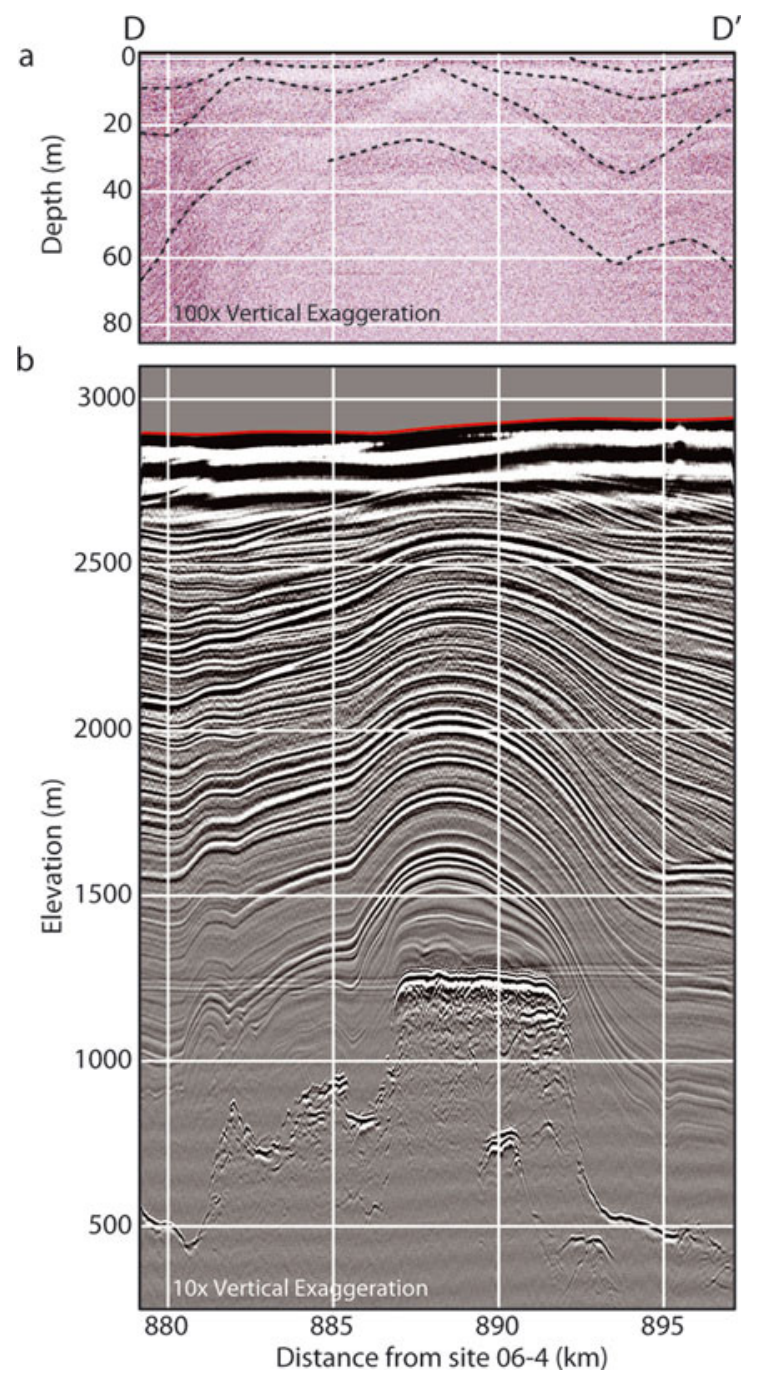

Fig. 5. Profile $D-D^{\prime}$ is an example of layers intersecting the ice surface. (a) $200 \mathrm{MHz}$ data show the intersection of near-surface layers with the surface. Some prominent reflectors are highlighted. (b) Migrated and elevation-corrected $3 \mathrm{MHz}$ data show that a subglacial mountain has created a vertical strain in the ice and a topographic high where aeolian erosion rates are higher. The horizontal stripes at $1200 \mathrm{~m}$ are an artifact of the horizontal filter.

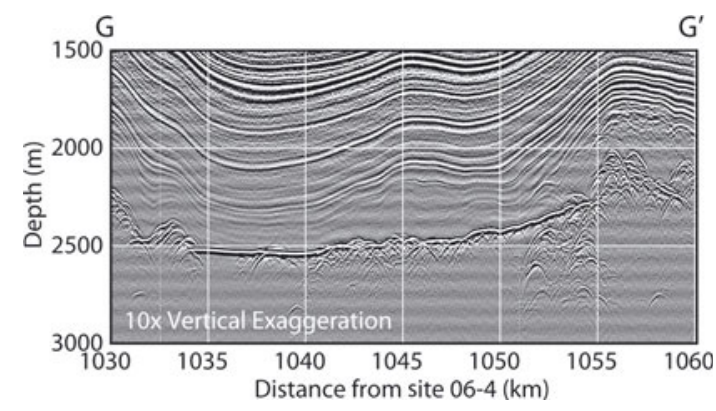

Fig. 7. Profile $\mathrm{G}-\mathrm{G}^{\prime}$ (high-gain channel) showing a subglacial lake ( $\mathrm{km}$ 1034-1041) and submerged terrain where water may be flowing down a slope (km 1046-1055).

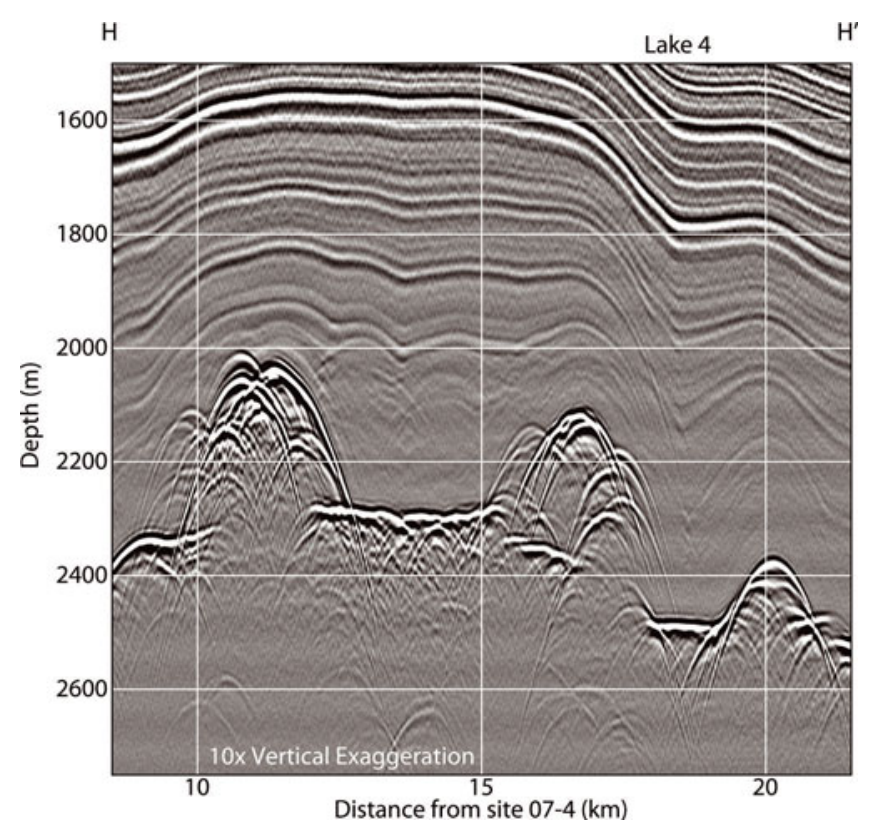

Fig. 8. Profile $\mathrm{H}-\mathrm{H}^{\prime}$ showing subglacial lake 4 , a small pond roughly $1 \mathrm{~km}$ across. The adjacent basin at km 12-15 has a strong reflector, but a rough surface, implying that the bed surface influences the ice-bed contact.
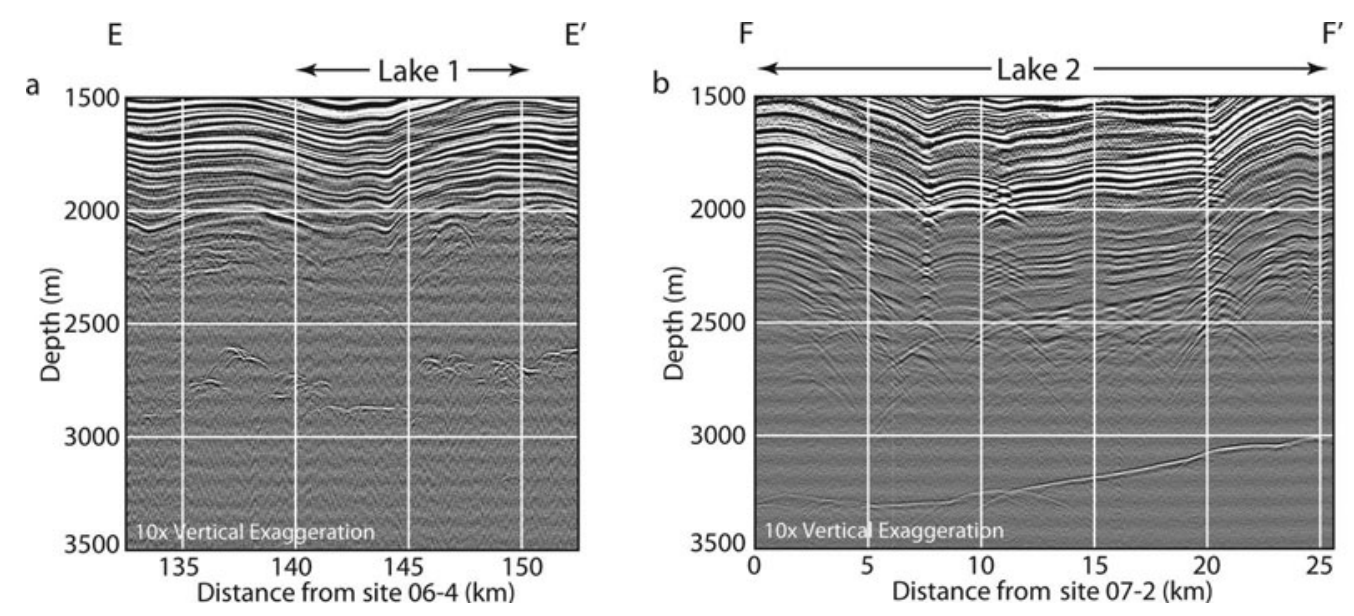

Fig. 6. (a) Profile $E-E^{\prime}$ showing the bed reflector and deep stratigraphy at lake 1 (defined by satellite from km 140-151). A deep cleft in the bedrock is visible in the rough bed surface. (b) Profile $\mathrm{F}-\mathrm{F}^{\prime}$ showing the bed reflector and deep stratigraphy at lake 2, location of the thickest ice seen in the 2007 traverse. The bed rises about $300 \mathrm{~m}$ along the center axis of the proposed lake bed. Reflectivity is relatively constant in both regions. 
provide a more quantitative comparison of the densityrelated reflections of the $200 \mathrm{MHz}$ radar with the conductivity-dominated reflections of the $3 \mathrm{MHz}$ radar system. The basal reflections at the subglacial lakes will provide a calibrated reference for the reflectivity analyses.

Mapping the spatial and vertical extent of the dune structures will lead to a better understanding of the temporal longevity of dune-forming conditions. As work continues to understand the wind and accumulation rate processes that govern dune formation, we may be able to recover past climatic conditions in these areas that will enhance our ability to tie together the ice-core glaciochemical and climate results.

The basal layer seen in Byrd Glacier and the differences between the northern and southern halves indicate the presence of two distinct regions feeding the main outlet glacier into the Ross Ice Shelf. Common-midpoint profiles recorded along the traverse should provide details about the dielectric attenuation within the drainage basin and allow comparisons with attenuation measured in West Antarctica (see MacGregor and others, 2007; Jacobel and others, 2009). Ongoing work to determine the formation history of the prominent basal deformation in the southern half of the drainage will lead to a better understanding of the contribution of ice from Byrd Glacier into the Ross Ice Shelf.

Determination of conditions within recently drained subglacial lakes is significant for understanding the impact of such lakes on ice flow. We have found that at least two lakes identified by satellite-derived surface topography have little or no water today. Subsequent altimeter evidence of ice surface inflation, indicative of water refilling the subglacial basin, would provide incentive for repeat radar surveys to determine the presence and volume of water. We will attempt to identify other likely sites of subglacial lakes utilizing more quantitative methods (e.g. Oswald and Gogineni, 2008).

\section{ACKNOWLEDGEMENTS}

We appreciate the comments from O. Eisen and two anonymous reviewers. We also thank the US-ITASE team members for making the data acquisition possible, and Raytheon Polar Services Corporation, the US Air National Guard and Kenn Borek Air for field logistics. This work was funded by US National Science Foundation grants OPP0440304 and OPP-0440533.

\section{REFERENCES}

Albert, M., C. Shuman, Z. Courville, R. Bauer, M. Fahnestock and T. Scambos. 2004. Extreme firn metamorphism: impact of decades of vapor transport on near-surface firn at a lowaccumulation glazed site on the East Antarctic plateau. Ann. Glaciol., 39, 73-78.

Anandakrishnan, S. and J.P. Winberry. 2004. Antarctic subglacial sedimentary layer thickness from receiver function analysis. Global Planet. Change, 42(1-4), 167-176.

Arcone, S.A., V.B. Spikes and G.S. Hamilton. 2005. Stratigraphic variation in polar firn caused by differential accumulation and ice flow: interpretation of a $400 \mathrm{MHz}$ short-pulse radar profile from West Antarctica. J. Glaciol., 51(174), 407-422.

Carter, S.P., D.D. Blankenship, M.F. Peters, D.A. Young, J.W. Holt and D.L. Morse. 2007. Radar-based subglacial lake classification in Antarctica. Geochem. Geophys. Geosyst., 8(3), Q03016. (10.1029/2006GC001408.)

Fahnestock, M.A., T.A. Scambos, C.A. Shuman, R.J. Arthern, D.P. Winebrenner and R. Kwok. 2000. Snow megadune fields on the East Antarctic Plateau: extreme atmosphere-ice interaction. Geophys. Res. Lett., 27(22), 3719-3722.

Frezzotti, M., S. Gandolfi and S. Urbini. 2002. Snow megadunes in Antarctica: sedimentary structure and genesis. J. Geophys. Res., 107(D18), 4344. (10.1029/2001JD000673.)

Fricker, H.A., T. Scambos, R. Bindschadler and L. Padman. 2007. An active subglacial water system in West Antarctica mapped from space. Science, 315(5818), 1544-1548.

Jacobel, R.W., B.C. Welch, D.J. Osterhouse, R. Pettersson and J.A. MacGregor. Spatial variation of radar-derived basal conditions on Kamb Ice Stream, West Antarctica. Ann. Glaciol., 50(51), 10-16.

MacGregor, J.A., D.P. Winebrenner, H. Conway, K. Matsuoka, P.A. Mayewski and G.D. Clow. 2007. Modeling englacial radar attenuation at Siple Dome, West Antarctica, using ice chemistry and temperature data. J. Geophys. Res., 112(F3), F03008. (10.1029/2006JF000717).

Oswald, G.K.A. and S.P. Gogineni. 2008. Recovery of subglacial water extent from Greenland radar survey data. J. Glaciol., 54(184), 94-106.

Smith, B.E., I.R. Joughin, H.A. Fricker and S. Tulaczyk. 2007. Subglacial water transport throughout Antarctica from ICESAT laser altimetry. [Abstract C53C-08.] Eos, 88(52), Fall Meet. Suppl.

Welch, B.C. and R.W. Jacobel. 2003. Analysis of deep-penetrating radar surveys of West Antarctica. Geophys. Res. Lett., 30(8), 1444. (10.1029/2003GL017210.)

Welch, B.C. and R.W. Jacobel. 2005. Bedrock topography and wind erosion sites in East Antarctica: observations from the 2002 USITASE traverse. Ann. Glaciol., 41, 92-96. 